\title{
Exploration of Needs for Marketing Talents and New Ideas for Talent Training in Heilongjiang Province Under the Background of Supply-Side Reforms
}

\author{
Rong Zhou, Xin Liu, Yajing Liu, Wei Gao and Xuehong Zhao \\ Harbin Finance University, China
}

\begin{abstract}
Throughout their deepening, supply-side reforms have been particularly carried out in strategic emerging industries and some regional cultural industries. To realize these development objectives, it is necessary to enhance marketing. Enterprises' competitiveness improvement, innovation and structural adjustment are inseparable from talent support. Under this background, efforts shall be made to analyze the needs for marketing talents, explore new ideas for cultivating creative talents and attain goals on talent training, so as to offer powerful talent support to enterprises which are conducting supply-side reforms.
\end{abstract}

Keywords: Talent Training; Supply-side; Marketing Talents.

\section{Introduction}

Heilongjiang Province, which is an important and old industrial base in China, has made considerable contributions to national economic construction. To facilitate revitalization and development of this old industrial base, vitality and driving forces of endogenous development shall be strengthened in northeastern China, and the supply-side structural reforms have offered new ideas for economic restructuring of Heilongjiang Province. Supply-side structural reforms focus on emancipating and developing social productive forces, promoting structural adjustments through reforms, reducing ineffective low-end supplies, expanding effective middle to high-end supplies, making supply structures flexibly adapt to changing demands and increasing total factor productivity. The primary objective of these reforms is to improve supplies to satisfy needs, in order that supplies can better accommodate people's growing needs for material cultures. In Heilongjiang Province, supply-side reforms, which have entered the most critical stage, focus on promoting fulfillment of five major tasks ("reducing excess capacity, reducing inventories, deleveraging, lowering costs and making up for deficiencies). According to actual situation of Heilongjiang Province, they aim to make breakthroughs at key difficult points, consistently highlight key points, particularly overcome difficulties, draw lessons from designated areas to drive overall development, practically carry out jobs and pertinently solve problems. These reforms are especially conducted in modern service industries (high-end equipment manufacturing, high-quality green food, dairy products and animal products), several strategic emerging industries and regional cultural industries where there is still space for overall domestic demands to increase and Heilongjiang Province gains advantages in supplies, so as to reinforce marketing, improve supply systems and efficiency, carry out vigorous market-oriented reforms, drive innovations and implement talent strategies. To enhance competitiveness of supply-side market entities, it is necessary to develop new motives for development and make every effort to open up new ways for complete revitalization. To put these new ideas of reform into practices, many creative and high-quality marketing talents are needed. However, economic and social development is out of accord with the needs for marketing talents.

\section{New Trends of Needs for Marketing Talents under the Background of Supply-side Reforms}

\subsection{Creative and Applied Talents Consolidating Talent Supply for "Local Manufacturing"}

Enterprises and talents are essential and fundamental for an innovation system. Despite enormous marketing employments, the employment threshold is low and talent supply is uncoordinated with the demands for talents. In particular, there is a great lack of creative marketing talents. These years, 
natural population growth has been slowed down in Heilongjiang Province. In 2018, the growth rate was below $0.6 \%$ in this province, where population migration and talent drain are serious problems. These problems mainly arise from too imbalanced industrial structure, over sluggish private economy, lack of incentive mechanism for marketing innovations and inadequate basic support (including work environment, salaries and career development), as a consequence of which Heilongjiang Province's ability to attract employment is limited. To solve these problems, the foremost task is to speed up efforts to balance industrial structure, because there will be insufficient employment opportunities if industrial structure is too unitary. To this end, greater efforts shall be made to promote development of modern service sectors (such as industries, tourism and finance), make creative enterprises better satisfy market demands, and vigorously facilitate development of private economy. According to data of the Heilongjiang Provincial Government, private economy accounted for 54\% of gross product of the province in 2018. It is evident that there is still much space for development of private economy in this province. To promote development of private economy, entrepreneurs are supposed to retain talents. After a survey, it is found that problems such as difficulties to sell products and severe mismatch between high-quality products and market shares/brand awareness are encountered by pillar enterprises of Heilongjiang Province which produce and process agricultural and animal products, including Great Northern Wilderness Agribusiness Group, Wondersun, Harbin Hi-Tech Soybean Food Co., Ltd and Wuchang Rice. To solve these problems, new marketing ideas and methods as well as creative marketing talents with excellent skills in planning and practices are needed.

\subsection{Necessity for Shaping Creative Talents' Personalities in "Supply-side Reforms"}

Personalities may be understood as talents' respective strengths and highlights, which reflect technical features of each industry. For marketing talents, their personalities mainly include great ambition, high confidence and independence. To cultivate creative talents, priority shall be given to moral ethics. It is necessary to correctly understand current policy conditions, actively make innovations, take up challenges, make strategic breakthroughs, become more powerful and achieve sustainable development. Creative marketing methods are primarily reflected from innovations such as creative customer management, selling skills, word-of-mouth marketing methods, derivative activities, massive linkage, advertising modes, incentive methods, cooperation and outreach strategies. Innovation means are not subjected to any limit.

\subsection{Great Popularity of "Technical" Interdisciplinary Marketing Talents}

"Technical" marketing talents refer to those who are competent for marketing management in some relatively technical and professional industrial departments and whose specialized knowledge about marketing is in line with technical characteristics of corresponding departments. Apart from a good command of professional knowledge about marketing, these talents also have to understand professional production technologies, develop marketing channels and analyze consumer behaviors by internet or smart platforms. For instance, dependent upon big data collection from multiple platforms, analysis and prediction of big data technologies, advertising can be more accurate and effective to create higher returns of investments for brands. Pursuant to the latest big data survey on marketing employments, lack of abilities to understand and analyze data is the greatest barrier to marketing talents' promotion and a cause of slow development in enterprise marketing. The marketing strategies drafted by a majority of marketing personnel are ineffective, because they are unable to properly utilize and analyze data. For example, how to manage or build user databases suitable for enterprises, analyze and use the data are universal questions that digital marketing managers should consider in enterprises of Heilongjiang Province. 


\section{New Ideas for Training Marketing Talents in Heilongjiang Province}

\subsection{Competitions and Models for Training Creative Talents}

Competitions can be organized to cultivate students' teamwork skills, creativity and awareness of competitions. With the changes of market demands for talents and reform of talent training models in universities, to train creative and practical talents has turned into an objective of higher education. Universities have attached greater and greater importance to cultivate students' abilities to integrate theories with practices, practical skills and creativity in practices. In their practices, discipline competitions are the most critical driving forces for cultivating students' creativity, so it is of great realistic significance for universities to deliver creativity education by studying functions and supporting conditions of discipline competitions. Greater efforts shall be made to enable marketing majors to master practical marketing skills through long-term cultivation of their creativity through competitions and training models.

\subsection{Remote Enterprise Classes}

Universities are supposed to develop cooperation and integrate resources with regional enterprises which are role models within their industries. Through the cooperation, enterprises can bring universities substantial industry resources, which are an integral part of education resources. In general, universities are capable of integrating resources, and it is important for them to integrate industry resources. Universities and enterprises ought to cooperate with each other to jointly train local marketing talents. They shall collaborate with each other, give their respective strengths into play and offer each other what they need. They ought to develop all-round and deep cooperation with each other in multiple forms to improve cultivation of marketing talents and train regional professional high-quality marketing talents. In enterprise classes, corporate personnel can have remote communications with students. Through these classes, students can perform cognitive learning to know about enterprises, posts, corporate working environment, organizational structures, marketing methods and product types, in order that students can perceptually understand professions in enterprises.

\subsection{Developing Correct Thinking and Strengthening Multiple Abilities}

The combination of disruptive technologies such as internet, cloud computing, big data and smart connections facilitates vigorous economic development. Traditional enterprises which haven't transformed themselves with internet and crossed the gaps of internet will fall far behind. Apparently, internet has posed new challenges to marketing personnel. Marketing personnel are expected to fully realize that in an internet age, they shall pay more attention to people, customers' communication methods, interests, personalities, lifestyles and change trends in marketing. Universities shall change their traditional marketing ideas and develop correct marketing mindsets for training professional marketing talents. (1) Active: They shall take initiatives to create chances for themselves and get more chances for training themselves or realizing their value. (2) "Empty cup" mindset: Marketing personnel are expected to fully realize that in an internet age, they shall pay more attention to people, customers' communication methods, interests, personalities, lifestyles and change trends in marketing.(3) Act: Marketing personnel are supposed to prove themselves and their value with actions. They shall take actions to really care about their customers and attain their goals. (4) Learning mindset: They ought to learn national policies, related economic rules and national macroeconomic or microeconomic policies to strategically improve themselves. They shall keep on learning from books, practices, experience and rivals to always win. In addition, marketing personnel need to systematically learn business management, marketing, psychology and public relations to continuously improve their knowledge structures, in order to become creative talents instead of mere talents who only master special knowledge and multiple skills. 


\subsection{Necessity for Government to Guide and Assist with Massive Training of Marketing Talents}

To promote regional economic development of Heilongjiang Province, various talents will be needed. To rely on talents cultivated within Heilongjiang Province and those attracted from other provinces, these talents shall be further educated and trained at higher levels, in order not only to meet requirements for lifelong learning, but also to provide greater support for regional economic development. On one hand, it is necessary to standardize the qualification accreditation system for marketing personnel, which is a guarantee for improving marketing personnel's cognition of employment and avoiding non-uniform capabilities of marketing personnel. On the other hand, government shall make their needs for marketing talents known by markets through third-party forces, namely organizations training marketing talents, and deal with information asymmetry in markets. Undoubtedly, marketing talents have to develop correct occupational outlooks and ideas on lifelong learning. In face of fierce market competitions, they shall clarify their objectives of career development, know orientations of their job promotions, adjust their attitudes towards their professions from time to time, and make contributions to regional economic development while improving themselves.

In China, close attention is paid to supply-side reforms, which are important measures keeping up with the times. To accommodate the needs for personalized high-quality education and promote sustainable development of higher education, it is necessary to drive supply-side reforms of higher education. Supply-side reforms highlight root causes of problems, which differs from incentive approaches of the short-time demand-side framework. Pertinent measures can be taken to improve talent training and innovate government-enterprise-university cooperation models, so as to train creative talents for regional supply-side reforms.

\section{Acknowledgments}

This work is supported by the research project of basic scientific research business fees of provincial universities in Heilongjiang Province, Project Number: 2018-KYYWF-E003.

\section{References}

[1]. Qingzhi Liu. Training Plans for Accounting Talents in Applied Universities under the Background of Supply-side Reforms [J]. China Township Enterprises Accounting, 2018 (12): 268-269.

[2]. Weidong Ning. Research on Training Models for Marketing Talents under the Background of "the Belt and Road" Initiative [J]. China Market, 2018 (3): 141-142.

[3]. Xin Liu. Reflection and Practices on Training Marketing Talents under the Background of Supply-side Reforms - A Case of Harbin Finance University [J]. Market Modernization, 2016 (12): 248-249. 